\title{
PSIKOLOGI KELUARGA ISLAM SEBAGAI DISIPLIN ILMU (TELAAH SEJARAH DAN KONSEP)
}

\author{
Ratna Suraiya \\ Institut Agama Islam (IAI) Al-Khoziny Sidoarjo \\ Email: ratnasuraiya88@gmail.com \\ Nashrun Jauhari \\ Institut Pesantren KH. Abdul Chalim Mojokerto \\ Email: nashrunjauhari25@gmail.com
}

\begin{abstract}
Islamic family psychology is currently being developed by a number of experts in the country, both in Islamic scientific studies and in handling practical Islamic family therapy. However, from the development efforts made, it often appears that the identity of the study is blurred between as an Islamic study and between a study from a Western perspective. The main asset to uncover the obscure curtain in the concept of this study is through tracing the psychological history of the Islamic family, so that it can provide an insight into the epistemological framework and the purpose of its study. The research succeeded in finding several points of findings: (1) Islamic family psychology emerged as a scientific study in the 1980s, after the development of family psychology studies in the 1960s in the West; (2) the emergence of Islamic family psychology studies was triggered by a mission to respond back to the pace of development of family psychology studies in the West which increasingly hegemony in the Islamic world; (3) the concept of Islamic family psychology is based on Islamic teachings which uphold human values, especially in the character of human creation; (4) the psychological dimension of each family person is always touched by Islamic teachings in order to create a Sakinah family.

Keywors: History, Family Psychology, Western Concepts and Islam.
\end{abstract}

\section{A. Pendahuluan}

Psikologi Keluarga Islam merupakan sebuah studi yang mempelajari tentang perilaku, fungsi mental, dan proses kejiwaan manusia pada kehidupan keluarga yang didasarkan kepada ajaran Islam. Psikologi keluarga Islam sangat dibutuhkan sebagai acuan dalam penanganan terapi keluarga di lembaga-lembaga klinik terapi seperti Kantor Urusan Agama (KUA), BKKBN, bahkan para hakim di Pengadilan Agama. Tujuan yang dicapai dari psikologi keluarga Islam adalah sebagai upaya untuk menciptakan kehidupan keluarga yang harmonis dan sejahtera.

Psikologi Keluarga Islam merupakan kajian baru dalam studi keislaman yang muncul di akhir abad 20. Pengkajian terma ini dilator-belakangi oleh perkembangan studi psikologi keluarga di Barat yang semakin meluas hingga mewarnai pemikiran akademisi muslim di dunia Islam. Hal ini memicu sejumlah ulama dan sarjanawan muslim untuk melakukan konseptualisasi kajian psikologi keluarga dalam perspektif Islam. Hanya saja upaya konseptualisasi tersebut hingga kini belum melahirkan kata sepakat mengenai perangkat metodologi yang dapat dianggap layak mewakili karakteristiknya sebagai kajian keislaman. 
Ada beberapa kecenderungan dalam pengembangan kajian psikologi keluarga Islam yang dilakukan para ahli saat ini. Pertama, kecenderungan untuk menerima wacana psikologi keluarga produk Barat sebagai wacana keislaman, sehingga berupaya untuk mencari dalil-dalil dari Al-Quran dan Sunnah. Kedua, kecenderungan untuk menerapkan teori-teori psikologi keluarga produk Barat sebagai pendekatan dalam mengkaji perilaku keluarga dalam kehidupan masyarakat muslim. Ketiga, kecenderungan untuk mengkaji konsep keluarga Islam dengan menjustifikasi adanya sentuhan terhadap dimensi kejiwaan manusia.

Dari tiga kecenderungan di atas butuh mendapat perhatian dan klarifikasi sehingga pengembangan psikologi keluarga Islam di tangan akademisi muslim ke depan benar-benar mencerminkan karakteristiknya sebagai studi keislaman. Untuk itu, sebagai upaya klarifikasi atas ragam kajian tersebut dibutuhkan sebuah informasi sejarah yang menguraikan tahapan-tahapan perumusan konsep psikologi keluarga Islam dari awal kemunculan hingga perkembangannya. Disadari sepenuhnya, bahwa kajian tentang sejarah psikologi keluarga Islam tidak banyak diwacanakan, bahkan nyaris terabaikan. Padahal wacana sejarah mempunyai urgensi tinggi untuk mengenali tipologi sebuah pemikiran.

Sejauh penelusuran hanya ditemukan empat kajian yang menyinggung sejarah psikologi keluarga. Pertama, kajian Ahmad Mubarak al-Kandari dalam buku 'Ilm alNafs al-Usri (1089). Buku tersebut belum menjangkau sejarah psikologi Islam secara khusus. Al-Kandari hanya mewacanakan perkembangan konsep keluarga dari periode primitif hingga munculnya kajian psikologi keluarga di Barat pada periode modern. ${ }^{1}$ Kedua, kajian Florence W. Kaslow dengan judul A Brief History of the Field of Family Psychology and Therapy (2007). Kaslow lebih focus meneliti sejarah perkembangan psikologi keluarga di dunia Barat. ${ }^{2}$ Ketiga, kajian dalam buku Sikulujiyyah al-Bi'ah al-Usriyyah wa al-Hayah karya tiga orang penulis: Su'ad 'Abd alRah\{man dan Samah Zahran dari Universitas 'Ayn al-Shams, dan Samirah Madkuri dari Universitas Kuwait. Wacana sejarah dalam buku ini merupakan penyederhanaan dan sistematisasi dari kajian al-Kandari sebelumnya. ${ }^{3}$ Dan keempat, kajian 'Atiyyah Saqar dalam Mawsu'ah al-Usrah tah\{ta Ri'ayah al-Islam, hanya wacana sebatas sejarah awal munculnya konsep keluarga dari Nabi Adam as, perpsketif para filsuf, hingga konsep keluarga Nabi Muhammad saw, tanpa disertai analisis psikologis. ${ }^{4}$

Artikel ini akan menghadirkan telaah sejarah psikologi keluarga Islam dan berupaya untuk menyajikan data-data akurat. Dengan sadar sepenuhnya bahwa hingga saat ini kajian-kajian ilmiah mengenai psikologi keluarga Islam masih jarang ditemukan. Terutama referensi sejarah kemunculan dan perkembangan konsepnya. Pembahasan artikel ini diawali dari sejarah konsep keluarga, yang merupakan pijakan terangunnya konsepsi psikologi keluarga. Pembahasan selanjutnya mengenai sejarah

${ }^{1}$ Ahmad Mubarak al-Kandari, 'Ilm al-Nafs al-Usri, (Kuwait: Maktabah al-Fallah, 1992), h. 26-28.

2 Florence W. Kaslow, "A Brief History of the Field of Family Psychology and Therapy" dalam Handbook of EMDR and Family Therapy Processes, (New York: John Wiley \& Sons Inc, 2007), h. 176.

3 Su'ad 'Abd al-Rahman dkk, Sikulujiyyah al-Bi'ah al-Usriyyah wa al-Hayah, (Kuwait-Egypt: Maktabah al-Fallah, 2016), h. 31-33.

4 'Atiyyah Saqar, Mawsu'ah al-Usrah tahta Ri'ayah al-Islam, (Kairo: Maktabah Wahbah, 2006), h. 48. 
kemunculan konsep psikologi keluarga di Barat, kemudian di dunia Islam, hingga perkembangan konsep kajian psikologi keluarga Islam di tangan para ahli saat ini.

\section{B. Pembahasan}

\section{B.1. Sejarah Konsep Keluaga \\ B.1.1 Kemunculan Konsep Keluarga}

Menurut wacana sejarah yang diakui oleh tiga agama Samawi (Islam, Kristen dan Yahudi), menyatakan bahwa kemunculan pertama konsep keluarga adalah dari kehidupan keluarga Nabi Adam as. ${ }^{5}$ Adam adalah sosok manusia pertama yang diciptakan Allah SWT. Kemudian Allah SWT menciptakan Hawa dari tulang rusuk Adam sebagai pendamping hidupnya hingga membentuk sebuah ikatan keluarga. Konsep keluarga pertama ini terbentuk atas perintah Allah SWT yang menyebut Hawa sebagai istri Adam dan surga menjadi tempat tinggalnya. Tujuannya adalah agar mereka berdua merasakan ketenteraman jiwa dan dapat beregenerasi. ${ }^{6}$

Dari sudut pandang psikologi, keberlangsungan hidup keluarga Adam di surga berjalan secara harmonis. Keharmonisan ini tampak jelas pada, (1) Prinsip kesepadanan (kafa'ah) antara Adam dan Hawa yang sama-sama manusia dengan martabat keluhurannya dan keduanya merupakan penduduk surga; (2) Terpenuhinya segala kebutuhan hidup berupa sandang, pangan dan papan, bahkan lebih dari itu, karena mereka tinggal di surga, sebuah tempat yang paling istimewa; (3) Adanya norma hukum yang mengatur perilaku Adam dan Hawa selama tinggal di surga, yaiti kebolehan untuk menikmati segala fasilitas surga kecuali mendekati sebuah pohon. ${ }^{7}$

Takdir Allah SWT memang menghendaki manusia sebagai pemimpin (khalifah) di bumi. ${ }^{8}$ Untuk itu, keluarga Adam pun akhirnya harus bermigrasi dari surga menuju planet bumi. ${ }^{9}$ Setelah berada di bumi keberlangsungan hidup keluarga Adam semakin menampakkan kodratnya sebagai sebuah keluarga manusia yang beregenerasi, berdinamika dan dihadapkan pada problem-problem keluarga. Konflik yang terjadi antara dua putra Adam, yaitu Qabil dan Habil, yang mengakibatkan kematian Habil, merupakan perseteruan yang timbul dari naluri kejiwaan manusia yang tidak terkontrol.10

Namun dengan kehadiran Shith as, putra ketiga Adam, menjadikan keluarga Adam ini kembali eksis sebagai keluarga harmonis dan penuh keluhuran. Pola pengasuhan anak yang dilakukan Adam dan Hawa pun tidak sebatas pemenuhan kebutuhan logistik tetapi juga pada kebutuhan edukatif dan keselamatan dari mala

5 'Atiyyah Saqar, Mawsu'ah al-Usrah..., h. 48,

${ }^{6}$ Q.S. Al-Baqarah ayat 35 dan Q.S. Al-A'raf ayat 189.

7 Agus Miswanto, "Keluarga Sakinah dalam Perspektif Ulama Tafsir: Studi terhadap Rumah Tangga Nabi Adam”, Cakrawala: Jurnal Studi Islam, Vol. 14 No. 2, Tahun 2019, h. 67-71.

8 Q.S. Al-Baqarah ayat 30.

9 Q.S. Al-Baqarah ayat 36.

10 Pasangan Adam dan Hawa dikaruniai sepasang putra putri dalam setiap kehamilan. Kehamilan pertama melahirkan Habil dan Labudah. Sedangkan yang kedua melahirkan Qabil dan Iklimah. Namun, Qabil menolak perintah sang ayah untuk melakukan perkawinan silang. Ia lebih memilih kawin dengan saudara perempuan kandungnya sendiri daripada saudara perempuan kandung dari Habil. Kemudian muncullah konflik saudara yang mengakibatkan kematian Habil. 
bahaya. Sebagaimana diceritakan Ibn Kathir bahwa Adam as menjelang wafatnya berwasiat kepada Shith mengenai tiga hal, yaitu berupa petunjuk tata cara beribadah, tentang terjadinya musibah angina topan yang akan melanda bumi, dan mengenai kelanjutan silsilah keluarga Adam yang sejati hanya berasal dari jalur keturunan Shith as. ${ }^{11}$

\section{B.1.2. Perkembangan Konsep Keluarga B.1.2.1 Periode Primitif}

Kehidupan anak-anak keturunan Adam As. terus berlanjut dan berjalan secara natural. Sejarah mencatat pola kehidupan manusia pada masa awal memang masih belum mengenal peradaban. Istilah 'primitif' (badawi) menjadi sebutan bagi mereka. Identitas primitif itu bisa terlihat pada model mata pencaharian seperti berburu dan bercocok tanam, cara berperilaku dan bahkan pola pikirnya. Dengan berjalannya waktu dan pergeseran tempat anak-anak Adam mulai meninggalkan ajaran bapaknya.

Orang-orang primitif cenderung hidup berkerumun dengan membentuk kabilah-kabilah. Kabilah adalah kelompok masyarakat kecil yang terdiri dari beberapa keluarga. Kabilah memegang otoritas penuh untuk menentukan berapa jumlah individu dalam sebuah keluarga. Pimpinan kabilah bisa memasukkan siapa saja sebagai angota dalam keluarga mana pun sesuai dengan kepentingan kabilahnya, walaupun tidak mempunyai hubungan darah atau kekerabatan. ${ }^{12}$

Perkawinan dalam tradisi masyarakat primitif lebih diorientasikan sekedar untuk memenuhi hasrat birahi. Sedangkan regenerasi dipahami sebagai proses biologis yang berjalan secara alamiah dari keberlangsungan hidup manusia, tanpa mengedepankan misi untuk memelihara eksistensi manusia sebagai pemelihara kelestarian bumi. Oleh sebab itu, pola hubungan antar individu dalam keluarga tidak didasarkan pada naluri kejiwaan yang suci, seperti rasa cinta dan kasih sayang, tetapi didasarkan pada pemenuhan hawa nadsunya. Sikap diskriminatif kepada perempuan dan anak-anak penyandang distabilitas menjadi dampak yang nyata dari pola pikir primitif. ${ }^{13}$

Namun demikian, ada sebagian kelompok masyarakat yang mulai menampakkan corak peradaban. Khususnya mereka yang mendiami kawasan yang menjadi perlintasan dakwah para Nabi dan tempat singga beberapa filsuf. Menurut 'Atiyyah Saqar, konsep keluarga mengenai pola hubungan suami istri dan pengauhan anak mulai dikenal masyarakat, antara lain di kawasan Mesir, Babilonia, Asyur, India,

11 Abu al-Fada' Isma'il ibn Kathir al-Damashqi, al-Bidayah wa al-Nihayah, (Ghizah Mesir: Dar Hajar, 1999), h. 230.

12 Ahmad Mubarak al-Kandari, 'Ilm al-Nafs al-Usri..., h. 26.

13 Harbert Spancer dan beberapa sosiolog lainnya, sebagaimana kutipan 'Atiyyah Saqar, menemukan bukti-bukti sejarah tentang tradisi masyarakat Neozeland kuno yang sama dengan tradisi Atab Jahiliyah walaupun letak geografisnya sangat jauh. Masyarakat Neozeland kuno tidak menyukai kelahiran anak perempuan sehingga mereka menyembelih setiap bayi perempuan yang baru dilahirkan. Pada setiap lima atau enam tahun sekali ada tradisi penyembelihan masal untuk anak-anak baik lakilaki maupun perempuan bagi keluarga yang mengalami krisis pangan. 'Atiyyah Saqar, Mawsu'ah alUsrah tahta Ri'ayah al-Islam, h. 71. 
Cina, Yunani dan Romawi, terhitung sebelum kelahiran 'Isa as. ${ }^{14}$ Setidaknya kisahkisah keluarga teladan seperti keluarga Ya'qub as, Ibrahim as, 'Imran, Luqman hingga cerita cinta Yusuf bersama Zulaihah yang termuat dalam Al-Quran bisa menjadi referensi kajian lebih lanjut.

\section{B.1.2.2 Periode Filosofis}

Periode filosofis yang dimaksud adalah pada masa kehidupan para filsuf di masa klasik. Dari para filsuf klasik lebih banyak menyinggung konsepsi keluarga sebagai modal berdirinya negara. Confucius (551 SM) tercatat sebagai filsuf tertua yang mengusung konsep keluarga dan membawanya ke dalam kehidupan bernegara.

Konsep keluarga terdapat pada ajaran Confucius tentang 'Wu Lun', yang berisi lima hubungan sosial, yaitu: hubungan antara raja dengan menteri, ayah dengan anak, kakak dengan adik, suami dengan istri, dan antara seorang individu dengan individu lainnya. ${ }^{15}$ Ia percaya bahwa keharmonisan itu merupakan wujud kepatuhan, seperti kepatuhan anak kepada orang tua, adik kepada kakak, istri kepada suami, dan kepatuhan mereka kepada penguasa yang harus dianggap sebagai 'bapak bangsa'. Bagi Confucius, sikap kepatuhan ini adalah salah satu kepribadian yang dimiliki oleh sosok 'Manusia Ideal' (Chun Tzu). ${ }^{16}$

Selanjutnya Aflatoun atau Plato (427-327 SM), seorang filsuf Yunani kuno. Konsep Plato tentang keluarga muncul sebagai reaksi atas peradaban kelam Yunani yang diskriminatif terhadap kaum wanita dan anak-anak. Untuk itu ia mewacanakan konsep keluarga sebagai pijakan untuk mewujudkan impiannya perihal 'masyarakat ideal'. Konsep keluarga yang dihadirkan sebenarnya cukup baik yang menjangkau masalah perkawinan, hak dan kewajiban suami istri, pengauhan anak hingga masalah perceraian. Hanya saja ide konseptual ini lebih tertuju kepada keluarga dari masyarakat kelas pekerja, yang menurut Plato, merupakan golongan masyarakat yang mempunyai peranan utama dalam membangun peradaban disbandingkan dengan mesyarakat kelas bawah. Inilah yang menyebabkan konsep keluarga Plato tidak disukai oleh orang-orang Yunani.

Aristoteles (394-322 SM), tampak lebih rinci berbicara mengenai konsep keluarga hingga pada struktur dan hubungan antar individu di dalamnya. Walaupun misi utama konsepsi keluarga ini sebagai metafor terbangunnya Negara Kota (Polis). Aristoteles menggambarkan struktur keluarga yang terdiri dari tiga unsur: orang tua, anak, dan budak dengan peranan masing-masing. ${ }^{17}$ Sedangkan pola hubungan dalam keluarga digambarkan sebagai sistem keluarga patrineal. Ia menyebut pemerintahan rumah tangga adalah monarki, karena setiap rumah diperintah oleh satu penguasa. Hubungan suami atas istri adalah pemerintahan republika, sedangkan atas anak-anak mereka adalah sistem monarki.

Pada abad 1 masehi muncul Arius Didymus yang melanjutkan gagasan Aristoteles. Didymus menuliskan jenis asosiasi dalam kehidupan keluarga. Ia

14 Ahmad Mubarak al-Kandari, 'Ilm al-Nafs al-Usri..., h. 73.

15 Lasiyo, "Sumbangan Filsafat Confucianisme dalam Menghadapi Abad XXI", Jurnal Filsafat Universitas Gajah Mada, (Yogyakarta: Desember 1994), h. 18.

16 Raymond Dawson, Confucius, (New York: Oxford University Press, 1981), h. 54.

17 Su'ad 'Abd al-Rahman, Sikilulujiyyah al-Bi'ah..., h. 36. 
menyebut asosiasi yang terjalin sebagai persatuan hukum antara pria dan wanita untuk mengurus anak-anak dan berbagi masalah rumah tangganya. Asosiasi dalam rumah tangga ini berpola monarki, aristokrasi dan demokrasi. Hubungan orang tua dengan anak-anak bersifat monarkis, suami dengan istri bersifat aristokrat, sedangkan anak-anak satu sama lain bersifat demokratis.

\section{B.1.2.3. Periode Islam}

Hadirnya Islam di abad ke 6 membawakan ajaran Allah SWT untuk umat manusia agar kembali ke jalan yang lurus, sesuai dengan fitrahnya, sehingga terwujud kemaslahatan dunia-akhirat. Untuk itu Islam mengajarkan bagaimana cara manusia berperilaku kepada Allah SWT (ibadah) dan berperilaku kepada sesama manusia (mu'amalah). Sedangkan perhatian Islam pada bidang keluarga didasari karena: keluarga dipandang sebagai lingkungan pertama yang membentuk kepribadian individu untuk menjadi hamba Allah SWT yang sejati, dan keluarga merupakan asas terbentuknya tata kehidupan sosial bahkan peradaban dunia.

Islam menghadirkan konsep keluarga secara teoritis dan secara praktis sekaligus. Secara teoritis konsep keluarga disampaikan melalui wahyu Allah dalam Al-Quran. Sedangkan secara praktis terimplementasi pada perjalanan hidup Nabi Muhammad saw yang tidak terlepas dari eksistensi sebuah keluarga. Rumusan konsep keluarga dalam Al-Quran, berdasarkan penelitian khusus tentang itu, adalah berpijak pada prinsip pemeliharaan Allah atas manusia (Nizam al-Rabbani). ${ }^{18}$ Dalam arti bahwa segala tuntunan keluarga yang ditetapkan oleh Allah akan selalu sejalan dengan dimensi kejiwaan manusia, sehingga hadirnya konsep keluarga Islam menjadi sebuah kebutuhan dasar bagi setiap individu untuk mencapai kebahagiaan dalam berkeluarga.

Dimensi kejiwaan yang dimaksud di atas bukan terbatas pada aspek jasmaniah (biologis dan sosiokultur) namun juga menjangkau aspek batiniah (psikis dan spiritual). ${ }^{19}$ Sebab, aspek jasmaniah dan aspek batiniah selalu berintegrasi dalam menentukan kehidupan dari seorang manusia. Sebagaimana integrasi aspek jasmaniah dan aspek batiniah ini diakui sebagai dasar pemikiran dari ilmu psikologi Islam. 20

Adapun konsep keluarga Islam secara praktis dapat kita amati pada perjalanan hidup Rasulullah saw yang telah melintasi dan sekaligus mempola berbagai tipe keluarga. Kehidupan Rasul diawali dari kelahirannya sebagai anak yatim. Beliau hidup selama 6 tahun bersama ibunda dalam lingkungan single parent family. Setelah

18 Ahmad Fa'iz, Dustur al-Usrah fi Zilal al-Qur'an, (Beirut: Mu'assasah al-Risalah, 1992), h. 52.

19 Sinergitas antara dimensi kejiwaan dengan konsep keluarga dalam Al-Quran salah satunya dapat kita amati pada perintah Al-Quran tentang pernikahan: Q.S. al-Ghariyat ayat 49, Q.S. Al-Shura ayat 11, Q.S. Al-A'raf ayat 189, dan Q.S. Al-Rum ayat 21. Dari ayat-ayat tersebut merefleksikan tiga kebutuhan manusia secara kejiwaan, (1) Kebutuhan iman, sebagai refleksi kebutuhan spiritual manusia yang mengakui dirinya adalah ciptaan Allah; (2) Kebutuhan hukum, sebagai refleksi kebutuhan fisik dan sosial manusia atas terwujudnya keamanan dan keteraturan hidup; dan (3) Kebutuhan akhlak, sebagai refleksi kebutuhan psikis manusia atas ketenangan batin dan harga diri. Lihat- Ahmad Fa'iz, Dustur alUsrah fi Zilal al-Qur'an, h. 33-34.

20 Samih 'Atif al-Zayn, Ma' rifah al-Nafs al-Insaniyyah fi al-Kitab wa al-Sunnah, (Beirut: Dar al-Kutub al-Lubnaniyyah, 1991), h. 172-173. 
ibunya wafat Rasul hidup bersama kakeknya, 'Abd al-Mutalib, yang tidak lain merupakan keluarga asuhan. Beberapa tahun kemudian Rasul hidup di keluarga Abu Talib, seorang paman yang belum memeluk agama Islam hingga akhir hayatnya. Beberapa tipe keluarga ini secara nyata telah berhasil membentuk kepribadian seorang manusia paling sempurna di muka bumi.

Selanjutnya, perjalanan hidup Rasulullah benar-benar mampu membentuk rumah tangga harmonis baik secara monogami maupun poligami. Keluarga monogami dijalani Rasulullah saw bersama Khadijah selama bertahun-tahun hingga sang istri menghembuskan nafas terakhir. Pernikahannya dengan Khadijah sama sekali tidak berambisi untuk melampiaskan hasrat birahinya, sebagaimana motif perkawinan orang-orang Jahiliyah. Ketulusan cinta mereka berdua pun tidak larut dalam budaya masyarakat Arab saat itu yang suka mengumpulkan banyak istri. Namun sepeninggal Khadijah ada kewajiban dakwah dan solidaritas kemanusiaan yang menuntut Rasulullah saw untuk menikahi delapan wanita janda dan seorang gadis kecil berusia 6 tahun.

Secara umum konsep keluarga adalah berupa tuntunan dan aturan syariat Islam tentang kehidupan keluarga. Para ulama telah banyak memberikan penjelasan dan perincian mengenai syariat keluarga Islam ini di tengah bahasan ilmu fiqih, ilmu akhlak dan bahkan dalam tafsir Al-Quran maupun sharah hadis. Materi yang disajikan meliputi tahapan-tahapan yang dijalani setiap individu dalam keberlangsungan keluarga, meliputi: (1) Tahap pembentukan keluarga, mulai dari tuntunan memilih jodoh, peminangan hingga akad nikah; (2) Tahap menjalin relasi dalam rumah tangga, yaitu dengan berlakunya hak dan kewajiban antara suami istri, anak hingga sanak kerabat; (3) Tahap penyelesaian konflik keluarga, berupa somasi damai dan perceraian; (4) Pembagian harta peninggalan melalui syariat hibah, wasiat dan waris.

Setiap ketetapan Allah dalam syariat pasti memiliki tujuan yang hendak dicapai, tidak terkecuali dengan keberadaan konsep keluarga Islam ini. Dengan mengetahui tujuan-tujuan yang dimaksud, kita juga dapat memahami karakteristik yang dimiliki konsep keluarga Islam. Jamal 'Atiyyah melalui teropong maqasid alShari'ah mengungkap ada tujuh macam tujuan: (1) Untuk menjalin relasi suami istri; (2) Untuk memelihara regenerasi manusia; (3) Untuk mewujudkan ketenteraman, cinta dan kasih saying; (4) Untuk memelihara garis nasab, (5) Untuk menjaga religiusitas keluarga, dan (7) Untuk mengatur sektor keuangan keluarga. ${ }^{21}$

\section{B.2. Munculnyas Kajian Psikologi Keluarga di Barat}

Abad 19 dalam sejarah peradaban Barat diakui sebagai era Kelahiran Baru (Renaisans). Pembaharuan diawali dengan adanya Revolusi Industri di Inggris, dari masyarakat agraris dan perdagangan ke masyarakat industri dan munculnya berbagai penemuan dalam bidang ilmu pengetahuan. Pembaharuan terpenting yang terjadi adalah 'antroposentrime' di mana manusia menjadi fokus pemikiran, karena itu era ini juga disebut sebagai era Humanisme. Reliasasinya antara lain berupa upaya

${ }^{21}$ Jamal al-Din 'Atiyyah, Nahwa Taf'il Maqasid al-Shari'ah, (Damaskus: al-Ma'had al-'Alami li alFikr al-Islami, 2001), h. 149. 
memperjuangkan Hak Asasi Manusia (HAM), menghapus diskriminasi wanita dan penelantaran anak.

Keluarga sebagai unit kecil kehidupan sosial dipandang paling potensial untuk mewujudkan sebuah peradaban yang ideal. Karena keluarga merupakan ruang kehidupan pertama bagi setiap individu dan memegang kendali dalam membentuk kepribadian. Hal inilah yang mendorong sejumlah ilmuwan untuk mengfungsikan teori-teori yang ada pada beberapa disiplin ilmu sebagai pendekatan dalam membangun profil kelurga ideal.

Munculnya kajian psikologi keluarga pertama kali yaitu sekitar tahun 1960-an dan mulai populer di tahun 1970-an. Kemunculan studi ini secara historis ditandai dengan penulisan karya ilmiah khusus. Kaslow (2007), ${ }^{22}$ mencatat karya ilmiah pertama yang ditulis oleh para perintis, yaitu: Ackerman (1961) A Dynamic Frame for The Clinical Approach to Family Conflict,23 Boszormenyi-Nagy dan Framo (1965) Intensive Family Therapy, ${ }^{24}$ Satir (1967) Conjoint Family Therapy, ${ }^{25}$ Whitaker (1976) The Hindrance of Theory in Clinical Work. ${ }^{26}$ Sejak saat itu mulai digelar beberapa konferensi dan didirikan klinik-klinik terapi untuk keluarga.

Catatan Kaslow di atas tidak jauh berbeda dengan James Bray. Pada tahun 1970 Bray menjumpai klinik terapi keluarga pertama di Amerika dengan nama 'Family Therapy Training and Development' yang berada di Universitas Houston. Bray menceritakan, operasional klinik tersebut melibatkan sejumlah ilmuwan dan praktisi yang terdiri dari ahli psikologi, psikiater, ahli sosiologi, ekologi dan para perawat kesehatan. Sedangkan metode yang digunakan dalam meneliti kejiwaan keluarga ini adalah melalui pendekatan multidisciplinary. ${ }^{27}$

Capra (1982) mengistilahkan pendekatan multi disipliner untuk studi psikologi keluarga sebagai perspektif sistemik (systemic perspective). Yaitu kesatuan dari tiga metode yang mencakup: penelitian kejiwaan melalui psikologi konvensional, penelitian perilaku keluarga perspektif sosiologi, dan penelitian lingkungan keluarga dengan melibatkan ilmu ekologi. ${ }^{28}$

Stanton (2009), ${ }^{29}$ menerjemahkan perspektif sistemik sebagai sebuah paradigma yang mengakui timbal balik dinamis antara individu, faktor interpersonal, dan lingkungan atau sistem makro dari waktu ke waktu dalam perilaku manusia.

22 Florence W.Kaslow, "A Brief History of the Field of Family Psychology and Therapy" dalam Handbook of EMDR and Family Therapy Processes, (New York: John Wiley \& Sons Inc, 2007), h. 438.

${ }^{23}$ N.W.Ackerman, "A Dynamic Frame for the Clinical Approach to Family Conflict" dalam N.W.Ackerman, F.L.Beatman dan S.N.Sherman (Ees), Exploring the Base for Family Therapy, (New York: Family Service Association of America, 1961), h. 52-67.

24 Boszormenyi-Nagy dan J.L.Framo, Intensive Family Therapy, (New York: Brunner/Mazel, 1985), h. 22.

25 V.Satir, Conjoint Family Therapy, (Palo Alto, CA: Science \& Behavior Books, 1967), h. 276.

${ }^{26}$ C.A.Whitaker, "The Hindrance of Theory in Clinical Work" dalam P.J.Guerin dkk, Family

Therapy: Theory and Practice, (New York: Gardner Press, 1976), h. 154-164.

${ }^{27}$ James H.Bray dan Mark Stanton, 'Preface' The Wiley-Blackwell Handbook of Family Psychology, (Blackwell Publishing Ltd, 2009), h. xiv.

28 Howard A. Liddle, "Family Psychology: Editors Introductionl", Journal of Family Psichology: Department of Family and Community Medicine University of California, September 1987, h. 9.

${ }^{29}$ Mark Stanton, "The Systemic Epistemology of the Specialty of Family Psychology" dalam- The Wiley-Blackwell Handbook of Family Psychology, (Blackwell Publishing Ltd, 2009), hlm. 5. 
Paradigma sistemik ini sangat membantu dalam psikologi karena memberikan kerangka kerja untuk konseptualisasi, menilai, mengobati, dan meneliti perilaku manusia. Sedangkan aplikasinya dapat dilakukan dengan mempertimbangkan variasi faktor (faktor interpersonal, makrosistemik dan individu) saat melakukan psikoterapi atau konsultasi dengan seorang individu, pasangan, keluarga, atau sistem sosial yang lebih besar.

Wacana para ahli mengenai paradigma sistemik di atas menunjuk pada kesatuan pandangan bahwa psikologi keluarga dibangun atas konseptualisasi elaboratif antara tiga disiplin ilmu, yaitu psikologi, sosiologi dan ekologi. Adapun sejumlah teori yang digunakan secara elaboratif dalam paradigm sistemik ini yaitu sebagai berikut:

\begin{tabular}{|c|c|c|}
\hline Disiplin Ilmu & Jenis Teori & Keterangan \\
\hline \multirow[t]{3}{*}{ Psikologi } & Teori Behavioral & $\begin{array}{l}\text { Pokok persoalan psikologi adalah tingkah laku, } \\
\text { tanpa melibatkan konsepsi kesadaran atau } \\
\text { mental. Pengusung teori: B.F. Skinner (1904- } \\
\text { 1990) }\end{array}$ \\
\hline & Teori Kognitif & $\begin{array}{l}\text { Teori ini memandang tingkah laku adalah } \\
\text { proses mental secara sadar (kognisi), individu } \\
\text { berperan aktif dalam menangkap dan menilai } \\
\text { stimulus yang datang sebelum melakukan } \\
\text { reaksi. Pengusung teori: Edward Tolman (1886- } \\
\text { 1959) }\end{array}$ \\
\hline & $\begin{array}{l}\text { Teori } \\
\text { Psikoanalisis }\end{array}$ & $\begin{array}{l}\text { Teori ini memandang tingkah laku didasari oleh } \\
\text { proses alam bawah sadar. } \\
\text { Pengusung teori: Sigmund Freud (1936) }\end{array}$ \\
\hline \multirow[t]{3}{*}{ Sosiologi } & $\begin{array}{l}\text { Teori Structural } \\
\text { Fungsional }\end{array}$ & $\begin{array}{l}\text { Teori ini melihat kehidupan sosial sebagai suatu } \\
\text { sistem yang seimbang, harmonis dan } \\
\text { berkelanjutan, sehingga bagian-bagian sistem } \\
\text { akan bekerja sesuai dengan fungsi masing- } \\
\text { masing. } \\
\text { Pengusung Teori: Harbert Spancer, Emile } \\
\text { Durkheim (1858-1917), dan Max Weber (1864- } \\
\text { 1920) }\end{array}$ \\
\hline & $\begin{array}{l}\text { Teori Konflik } \\
\text { Sosial }\end{array}$ & $\begin{array}{l}\text { Perubahan sosial tidak terjadi melalui proses } \\
\text { penyesuaian nilai-nilai yang membawa } \\
\text { perubahan, tetapi terjadi akibat adanya konflik } \\
\text { yang menghasilkan } \\
\text { kompromi yang berbeda dengan kondisi semula } \\
\text { Dasar teori ini dari Karl Marx dan populer di } \\
\text { tahun } 1960 \text {-an. }\end{array}$ \\
\hline & $\begin{array}{l}\text { Teori Interaksi } \\
\text { Simbolik }\end{array}$ & $\begin{array}{l}\text { Perilaku sosial tampak pada gerak isyarat } \\
\text { (gesture) dan maknanya, sehingga berpengaruh } \\
\text { pola interaksi. } \\
\text { Pengusung teori : George Herbert Mead (1934) }\end{array}$ \\
\hline
\end{tabular}




\begin{tabular}{|c|l|l|}
\hline & $\begin{array}{l}\text { Teori } \\
\text { Pertukaran } \\
\text { Sosial }\end{array}$ & $\begin{array}{l}\text { Perilaku individu masuk ke dalam hubungan } \\
\text { pertukaran dengan pihak lain karena } \\
\text { memperoleh imbalan } \\
\text { Pengusung teori George Caspar Homans (1961) }\end{array}$ \\
\hline Ekologi & $\begin{array}{l}\text { Teori Family } \\
\text { Development }\end{array}$ & $\begin{array}{l}\text { Kehidupan keluarga akan mengalami } \\
\text { perkembangan yang dipengaruhi oleh } \\
\text { lingkungan, menurut tahapan-tahapan } \\
\text { perjalanan waktu. Teori ini diusung oleh Gregor } \\
\text { Mendel (1822-1884) lalu dikembangkan oleh } \\
\text { Duvall (1957) untuk perkembangan keluarga. }\end{array}$ \\
\hline
\end{tabular}

Sejumlah teori di atas merupakan perangkat yang menjadi pilar terbangunnya kajian psikologi keluarga. Adanya keterlibatan teori-teori psikologi adalah didasarkan pada substansi psikologi keluarga ini yang mengkaji proses kejiwaan manusia, walaupun hanya pada lingkup keluarga. Sedangkan keterlibatan teori-teori sosial didasarkan pada kebutuhan untuk mengamati bentuk keluarga, tipe, struktur, fungsi dan peran individu, serta gejala-gejala sosial lainnya yang muncul dalam kehidupan keluarga. Sementara keterlibatan teori ekologi adalah untuk dapat meninjau lebih dekat terhadap faktor lingkungan yang melingkupi keberlangsungan hidup keluarga.

Hadirnya psikologi keluarga bersama pendekatan multi-disipliner ini telah berhasil mengubah identitasnya dari kajian keluarga perspektif psikologis menjadi sebuah disiplin ilmu yang mandiri. Dari perangkat teroitik yang telah terkonsep tersebut setidaknya cukup untuk menunjukkan obyek formal dari disiplin ilmu ini. Sedangkan perilaku anggota keluarga yang menjadi sorotan utama kajiannya merupakan obyek material yang cukup empiris. Selain menghadirkan wacana teoritis, psikologi keluarga juga memiliki fungsi aplikarif, yaitu sebagai pedoman utama dalam penanganan terapi keluarga, dan sekaligus sebagai wawasan kepada masyarakat tentang strategi pembangunan keluarga sejahtera.

Memasuki abad 21 psikologi keluarga mengalami perkembangan yang tidak kalah dengan cabang-cabang psikologi lainnya. Upaya pengembangan psikologi keluarga semakin banyak dilakukan baik dalam stdui ilmiah maupun uji praktek pada klinik terapi. Kaslow mencatat teori-teori baru yang bermunculan di Barat pada periode kontemporer ini, ${ }^{30}$ antara lain: Bowenian Systems Theory, ${ }^{31}$ Contextual or

${ }^{30}$ Florence W.Kaslow, “A Brief History of the Field..., h. 439.

31 Bowenian Systems Theory dikembangkan oleh Murray Bowen pada tahun 1967. Teori ini berbicara tentang proses diferensiasi personal untuk menumbuhkan kesadaran diri atas pemenuhan hak dan kewajiban dalam kehidupan keluarga. 
Relational Therapy, ${ }^{32}$ Symbolic-Experimental Family Therapy, ${ }^{33}$ Comunication Model, ${ }^{34}$ Structural Family Therapy, ${ }^{35}$ Behavioral and Cognitif-Behavioral Therapy, ${ }^{36}$ dan beberapa teori lain yang merupakan pengembangan dari konsep dasar psikologi keluarga.

Secara garis besar kerangka konseptual dari terma psikologi keluarga dapat digambarkan pada skema di bawah ini:

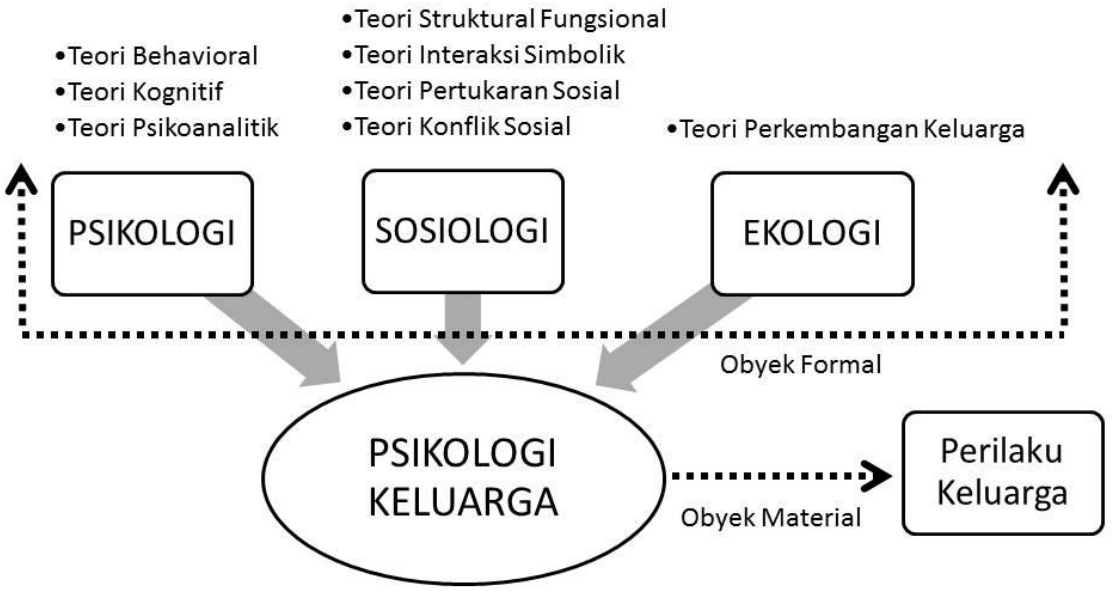

\section{B.3. Sejarah Munculnya Kajian Psikologi Keluarga Islam B.3.1 Psikologi Islam sebagai Pijakan Konsep}

Kemunculan psikologi keluarga Islam tidak dapat dipisahkan dengan hadirnya konsep besar psikologi Islam. Sebagaimana kita ketahui bersama bahwa psikologi keluarga merupakan cabang dari ilmu psikologi, maka demikian pula psikologi keluarga Islam merupakan perpanjangan tangan dari psikologi Islam. Psikologi Islam mulai tampil sebagai sebuah disiplin ilmu tentang gejala-gejala kejiwaan manusia

32 Contextual/ Relational Therapy oleh Ivan Boszormenyi-Nagy sejak tahun 1973. Ini adalah sebuah teori terapi keluarga dengan fokus ganda pada pembangunan relasi antar generasi secara etis dan bertanggung jawab, seperti pengaturan warisan, kesetiaan, dan hutang piutang keluarga.

33 Symbolic-Experimental Family Therapy oleh Napier dan Forest S. Whitaker (1978). Yaitu sebuah teori terapi keluarga dengan fokus menguraikan makna simbolik komunikasi psikotik. Teori ini menawarkan sketsa keluarga prototipikal dalam terapi, seperti kehangatan pribadi, keceriaan, selera humor, belas kasih, bakat intuitif.

34 Comunication Model oleh Gregory Bateson dan rekan-rekannya yang tergabung dalam The Mental Research Institute, Palo Alto California, sejak tahun 1950 an. Comunication Model merupakansebuah teori komunikasi ikatan ganda (double bind communications) dalam bentuk paradoks, saling bertentangan antara pesan eksplisit dan makna implisit. Teori terapi ini diperuntukkan bagi keluarga yang cenderung melakukan kekerasan (skizofrenia).

35 Structural Family Therapy oleh Minuchin (1987). Teori lebih ditujukan sebagai metode terapi untuk keluarga ekonomi rendah dan penanganan psikis anak-anak nakal. Teori ini lebih menekankan pada upya restrukturisasi subsistem keluarga dan pembatasan pola interaksi untuk memfasilitasi perubahan.

36 Behavioral and Cognitif-Behavioral Therapy oleh Jacobson dan Margolin (1979). Teori terapi ini menggabungkan prinsip-prinsip dari pembelajaran sosial dan teori pertukaran social, yang mengajar pasangan untuk menggunakan keterampilan untuk meningkatkan hubungan mereka, sehingga meningkatkan kepuasan dalam pernikahan. Teknik perilaku diterapkan pada pengobatan disfungsi seksual pada pasangan. 
yaitu sejak tahun 1950-an. ${ }^{37}$ Tampilnya psikologi Islam diawali dengan adanya "Gerakan Psikologi Islam" di Amerika Serikat, hingga pada tahun 1978 diadakan Symposium on Pshichology and Islam di Riyadh, Arab Saudi. ${ }^{38}$ Gerakan ini terus berlanjut dan psikologi Islam terus mendapatkan perhatian dari kalangan ulama dan sarjanawan muslim melalui forum-forum diskusi maupun penulisan karya-karya ilmiah.

Beberapa karya ilmiah psikologi Islam yang bermunculan pasca symposium tersebut, antara lain: The Dilemma of Muslim Psychologists karya Malik ibn Badri (1975), ${ }^{39}$ Nahw 'Ilm al-Nafs al-Islami karya Hasan Muhammad Sharqawi (1979), 'Ilm alNafs al-Mu'asir fi al-Islam karya Muh\{ammad Mahmud (1983), al-Qur'an wa 'Ilm al-Nafs karya Muh\{ammad Uthmani Najati (1985), ${ }^{40}$ al-S\{ih\{h\{ah al-Nafsiyyah fi Daw' 'Ilm alNafs wa al-Islam karya Kamal Ibrahim Musa dan Muhammad 'Awdah (1986):, ${ }^{41} M a ' r i f a h$ al-Nafs al-Insaniyyah fi al-Kitab wa al-Sunnah karya Samih 'Atif alZayn (1991), ${ }^{42}$ serta yang lainnya.

Psikologi Islam saat ini hadir sebagai sebuah disiplin ilmu keislaman bersama kerangka epustemologi yang kokoh. Psikologi Islam secara konseptual berpijak pada prinsip-prinsip keislaman yang paling fundamental. Yaitu berpijak pada Al-Quran dan Sunnah yang di dalamnya memberikan wawasan tentang jiwa manusia, kemudian berpijak pada hasil interpretasi para ulama di dalam kitab-kitab ilmu alNafs, baru selanjutnya menyanding-bandingkan dengan teori-teori psikologi Barat melalui filterasi yang cukup ketat.

Perbedaan psikologi Islam dan psikologi Barat tampak menonjol pada konsepsinya tentang manusia dan metode analisis yang digunakan. Psikologi Barat mutlak menggunakan kemampuan rasio sebagai patokan dalam mengungkap kejiwaan manusia, sedangkan psikologi Islam mendekatinya dengan memfungsikan rasio dan keimanan sekaligus. Ditinjau dari segi obyek analisisnya pun cukup berbeda, psikologi Barat tertuju pada dimensi fisik-biologi, dimensi kejiwaan, dan dimensi sosiokultural. Sementara itu psikologi Islam lebih menjangkau pada dimensi kerohanian, dimensi spiritual, suatu wilayah yang menjadi pantangan bahkan tidak pernah disentuh oleh pemikiran Barat karena perbedaan landasan. ${ }^{43}$

Psikologi Islam sebagai disiplin ilmu keislaman dapat menjalankan fungsinya untuk menjawab segala problematika kehidupan manusia yang terkait dengan aspek

37 Walaupun persoalan kejiwaan manusia (al-Nafs) sudah terwacana di masa ulama klasik, seperti al-Kindi (801-866 M.), Ibn Sina (980-1037 M), dan al-Ghazali (1043-111M.), namun masih dalam terminologi kajian filsafat, ilmu kalam dan tasawuf.

38 Ema Yudiani, "Pengantar Psikologi Islam”, dalam JIA, Vol.XIV, No.2, Desember 2013, h. 177.

${ }^{39}$ Malik Badri, The Dilemma of Muslim Psychologists, Terj. Muna Kantibay Abu Qarjah, (Oman: Dar Dubaynu, 2010).

${ }^{40}$ Muhammad Uthmani Najati, Al-Qur'an wa 'Ilm al-Nafs, (Kairo: Dar al-Shuruq, 1985), h. 37.

${ }^{41}$ Kamal Ibrahim Musa dan Muhammad 'Awdah: al-Sihhah al-Nafsiyyah fi Daw' 'Ilm al-Nafs wa alIslam, (Kuwait: Dar al-'Ulum, 1986), h. 97.

42 Samih 'Atif al-Zayn, Ma'rifah al-Nafs al-Insaniyyah..., h. 102.

43 Samih 'Atif al-Zayn menjelaskan karakteristik dari konsep psikologi Islam, yaitu ada tiga: (1) Mengintegrasi antara dimensi zahiri (fisik-biologis dan sosiokultural) dengan dimensi dakhili (rohanispiritual) yang melingkupi ruang kehidupan seorang manusia; (2) Mengintegrasi tiga unsur daya hidup manusia, yaitu jasmani, rohani dan mentalitas; dan (3) Mengintegrasi antara aspek lahiriah yang mengekspresikan perilaku dan aspek batiniah yang bertindak sebagai penggerak perilaku. 
kejiwaan. Sebagaimana komperhensifitas ajaran Islam yang memberikan pemeliharaan atas kelangsungan hidup manusia di dunia dan akhirat, menuntut psikologi Islam untuk bertanggung jawab untuk menjaga normalitas kejiwaan manusia dan pembinaannya hingga pada level kesucian jiwa (tazkiyyah al-Nafs).

Oleh sebab itu, pengembangan psikologi Islam yang diperjuangkan para ahli dewasa ini tertuju pada pengembangan bidang teoritis dan bidang praktis sekaligus. Wujud nyata dari pengembangan psikologi Islam teoritis adalah karya-karya ilmiah psikologi berdasarkan Al-Quran dan Sunnah sebagaimana yang disebutkan di atas. Sedangkan pengembangan psikologi Islam praktis terproyeksi pada kajian psikologi pendidikan Islam, psikologi ekonomi Islam, psikologi politik Islam, dan termassuk psikologi keluarga Islam.

\section{B.3.2. Munculnya Kajian Psikologi Keluarga Islam}

Perhatian besar para ilmuwan Barat dalam mengembangkan psikologi keluarga tampaknya telah menanamkan benih kepedulian bagi akademisi muslim Timur Tengah untuk menyentuh dimensi kejiwaan dalam kehidupan keluarga. Penanganan konflik-konflik keluarga melalui pendekatan hukum, dengan munculnya Qanun Ahwal al-Shakhsiyyah, belum mampu menyentuh titik pangkal munculnya konflik. Apalagi untuk menumbuhkan kesadaran kepada masyarakat atas keharmonisan keluarga secara implementatif. Untuk itu, beberapa akademisi mulai mengkaji wacana psikologi keluarga dari Barat dan menerjemahkan buku-buku psikologi keluarga ke bahasa Arab.

Diawali oleh Zakariya Ibrahim, seorang akademisi berkebangsaan Arab Mesir, yang menulis buku berjudul Sikulujiyyah al-Mar'ah dan al-Zawaj wa al-Istiqrar al-Nafsi (1957). ${ }^{44}$ Walaupun dua buku tersebut dipublikasikan di kawasan Timur Tengah, yang mayoritas penduduknya beragama Islam, namun penulisnya masih mewacanakan konsepsi pemikiran Barat. Beberapa penulis berikutnya antara lain karya tulis: Salih 'Abd al-'Aziz; al-S\{ih\{h\{ah al-Nafsiyyah li al-H\{ayah al-Zawjiyyah (1972). ${ }^{45}$ Muh\{ammad Khalifah Barakat; 'Ilm al-Nafs al-Tarbawi fi al-Usrah (1977), ${ }^{46}$ Iqbal Muh\{ammad Bashir; Dinamikiyyah al-'Ala>qat al-Usriyyah (1986), 47 Tuma George al-Khuri; Sikulujiyyah al-Usrah (1988),', dan 'Adnan 'Abd al-Karim al-Shati; Mudhakarat fi Sikulujiyyah al-'Alaqat al-Usriyyah (1988). ${ }^{49}$

Dengan menyadari adanya perbedaan sudut pandang antara Islam dan Barat, mendorong para akademisi muslim untuk kembali kepada konsep ilmu pengetahun

\footnotetext{
${ }^{44}$ Menurut catatan Zakariya Ibrahim dalam prolog buku kedua, disebutkan bahwa buku pertama Sikulujiyyah al-Mar'ah terbit pada tahun 1957 cetakan Maktabah Masr, kemudian disusul buku yang kedua. Lihat Zakariya Ibrahim, al-Zawaj wa al-Istiqrar al-Nafsi, (Kairo: Maktabah Masr, 1978), h. 5.

45 Salih 'Abd al-'Aziz, al-Sihhah al-Nafsiyyah li al-Hayah al-Zawjiyyah, (Kairo: al-Hay'ah alMisriyyah al-'Ammah li al-Kitab, 1972), h. 161.

46 Muh\{ammad Khalifah Barakat 'Ilm al-Nafs al-Tarbawi fi al-Usrah, (Kuwait: Dar Al-Qalam, 1977), h. 62 .

47 Iqbal Muhammad Bashir, Dinamikiyyah al-'Alaqat al-Usriyyah, (Iskandariyah: al-Maktabah alJami'i al-Hadith, 1986), 122.

48 Tuma George al-Khuri, Sikulujiyyah al-Usrah, (Beirut: Dar Al-Jayl, 1988), 12.

49 'Adnan 'Abd al-Karim al-Shati, Mudhakarat fi Sikulujiyyah al-'Alaqat al-Usriyyah, (Kuwait: Matabi` Kuwayt Taymuz, 1988), 211.
} 
Islam, khususnya pada bidang psikologi yang sudah terumuskan. Upaya konseptualisasi psikologi keluarga Islam pertama dilakukan oleh Ahmad Mubarak al-Kandari, akademisi dari Universitas Kuwait melalui sebuah buku berjudul ' $\mathrm{Ilm}$ alNafs al-Usri karya (1089). ${ }^{50}$

Al-Kandari bersama buku itu menawarkan konsep psikologi keluarga Islam secara ilmiah bersama obyek formal dan obyek materialnya. Pada obyek formal melibatkan lima jenis pendekatan yaitu: structural fungtional theory, symbolic interaction theory, family development theory, social learning theory, dan psychoanalisis theory. ${ }^{51}$ Sedangkan sebagai obyek material ia menyoroti konsep keluarga dalam ajaran Islam; mulai dari tuntunan memilih jodoh, prinsip kafa'ah, akad nikah, hak dan kewajiban suami istri, hingga mengenai pengasuhan anak. 52

Wacana keislaman dalam buku al-Kandari lebih tampak pada bahasan obyek materialnya. Sementara pada obyek formal nyaris tidak dilakukan uji kelayakan teori untuk dipergunakan sebagai pisau analisis terhadap ajaran Islam. Barangkali ini merupakan corak kajian psikologi keluarga Islam di awal kemunculannya. Namun tidak berlebihan bila wacana al-Kandari kita sebut sebagai sebuah kajian tentang konsep keluarga Islam dalam perspektif psikologi keluarga Barat.

Upaya konsepstualisasi psikologi keluarga Islam selanjutnya hadir pada tahun 1991. Yaitu dengan hadirnya buku berjudul al-'Alaqah al-Zawjiyyah wa al-Sihah alNafsiyyah: fi al-Islam wa 'Ilm al-Nafs, karya Kamal Ibrahim Musa. Sesuai dengan judulnya, buku itu melakukan studi komperatif antara konsep pemikiran Barat dan Islam. Uji komperatif tidak hanya dilakukan pada konsep keluarga sebagai obyek material kajiannya. Akan tetapi, dilakukan uji kelayakan, melalui upaya filterasi atas teori-teori Barat dan sekaligus melakukan konsolidasi kepada dalil-dalil keislaman dari Al-Quran dan Sunnah.

Sosok Kamal Ibrahim memang dikenal cukup lama berkecimpung dalam pengembangan psikologi Islam. Sejumlah karya ilmiah mengenai psikologi Islam telah banyak ditulis. Untuk itu dalam perumusan psikologi keluarga Islam ini ia tampak berupaya menampilkan misi Islamisasi ilmu di bidang psikologi. Pada landasan konsep ia merancang empat tahapan metodik, yaitu: (1) Membangun konsepsi Islam tentang tabiat dasar manusia beserta tujuan-tujuan penciptaannya; (2) Berpijak pada prinsip-prinsip kewahyuan tanpa interpretasi yang melampaui batas; (3) Merujuk kepada wacana ilmu jiwa dari Al-Quran, Sunnah dan literatur-literatur ulama klasik; dan (4) Mengkomparasikan konsep psikologi Islam dengan teori-teori psikologi Barat yang berkembang di era modern. ${ }^{53}$

Pada tahun 2008 di Indonesia muncul buku 'Psikologi Keluarga Islam Berwawasan Gender' karya Mufidah Ch. Karya ini merupakan buku pertama psikologi keluarga Islam di tanah air yang patut mendapat apresiasi besar. Karena hingga penulisan artikel ini belum ditemukan karya tulis lain yang secara khusus dan utuh mewacanakan psikologi keluarga Islam dari akademisi tanah air. Baru pada tahun

50 Ahmad Mubarak al-Kandari, 'Ilm al-Nafs al-Usri..., h. 115.

51 Ibid, h. 57-62.

$52 \mathrm{Ibid}, \mathrm{h} .67$.

53 Kamal Ibrahim Musa, al-'Alaqah al-Zawjiyyah wa al-Sihhah al-Nafsiyyah: fi al-Islam wa 'Ilm al-Nafs, (Kuwait: Dar Al-Qalam, 1995), h. 16. 
2014/2015 psikologi keluarga Islam mulai dimasukkan sebagai mata kuliah di Fakultas Syari'ah Universitas Islam Negeri (UIN) Malang. ${ }^{54}$ Sejak saat itulah bermunculan karya-karya tulis baik artikel jurnal maupun makalah kuliah yang mengangkat terma ini.

Perspektif gender dalam kajian Mufidah adalah dimaksudkan untuk mengangkat kedudukan wanita yang cenderung terdiskriminasi pada ruang kehidupan keluarga di Indonesia. Sementara itu, materi-materi penting yang menjadi obyek kajian psikologi keluarga lebih diarahkan pada upaya pembangunan keluarga sejahtera perspektif Islam. Materi-materi tersebut meliputi: profil keluarga sakinah, menajemen rumah tangga, komunikasi antar-anggota keluarga, pengembangan potensi dalam keluarga, strategi mengatasi konflik dan penyelesaian masalah, peran dan tanggungjawab anggota keluarga yang berkesetaraan gender, internalisasi dan eksternalisasi nilai-nilai Islam dalam keluarga. 55

Selanjutnya pada tahun 2016 dari Universitas 'Ayn al-Shams di Mesir menerbitkan sebuah buku psikologi keluarga Islam untuk diktat perkuliahan. Buku tersebut menghadirkan konsep psikologi keluarga secara utuh, dilengkapi dengan perangkat metodologi perspektif Barat dan Islam, bahkan disertai cara kerja teori dalam penelitian perilaku keluarga. Buku itu berjudul Sikulujiyyah al-Bi'ah al-Usriyyah wa al-Hayah. Tim penulis buku yaitu Su'ad 'Abd al-Rahman dan Samah Zahran dari Universitas 'Ayn al-Shams, dan seorang psikolog dari Universitas Kuwait bernama Samirah Madkuri. ${ }^{56}$

Penulisan buku tersebut cukup sistematis dengan menghadirkan bahasanbahasan utama yang menjadi kebutuhan para akademisi. Pembahasan diawali dari wacana definitif tentang psikologi keluarga, urgensi pengkajiannya, sejarah singkat perumusan. Pembahasan dilanjutkan dengan menyajikan materi-materi pokok psikologi keluarga yang diikuti pengenalan teori dan sekaligus contoh aplikasinya dalam penelitian kejiwaan keluarga.

Adapun wacana konseptual dari kemunculan psikologi keluarga ini dapat digambarkan pada skema umum di bawah ini:

${ }^{54}$ Mufidah Ch, Psikologi Keluarga Islam Berwawasan Gender, (Malang: UIN Maliki Press, 2014), h.

vi.

55 Ibid, h. 61.

56 Su'ad 'Abd al-Rahman dkk, Sikulujiyyah al-Bi'ah al-Usriyyah wa al-Hayah, (Kuwait-Egypt: Maktabah al-Fallah, 2016), 91. 


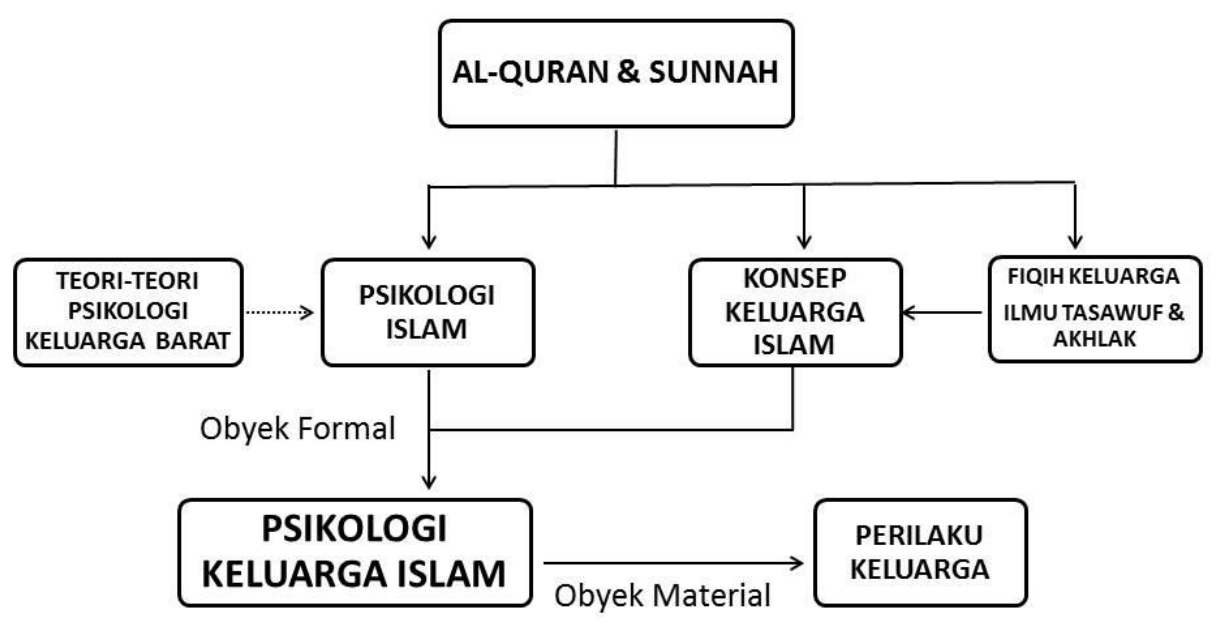

\section{Simpulan}

Seiring dengan berkembangnya peradaban manusia, perjalanan sejarah ini telah mengantarkan pada transformasi kajian keluarga Islam dari wacana normatif menuju kajian berbasis psikologis Islami. Dari wacana sejarah yang telah dipaparkan dapat ditarik beberapa kesimpulan penting sebagai temuan penelitian. Pertama, psikologi keluarga Islam secara konseptual berpijak pada prinsip universalitas Islam yang menjunjung tinggi nilai kemanusiaan. Sehingga, semua ajaran yang ada dalam Islam khususnya mengenai konsep keluarga akan selalu sinergis dengan tabiat dasar dan kejiwaan manusia sebagaimana fitrah penciptaannya. Kedua, perkembangan konsep keluarga berjalan secara holistik, yang diawali dari tipikal keluarga yang religious dan kemudian kembali kepada tipikal religius. Karena religiusitas merupakan tabiat dasar manusia. Hal ini tampak pada religiusitas keluarga Adam as, yang kemudian mulai memudar pada periode primitif dengan diskriminasi terhadap kaum perempuan dan anak cacat, lalu periode filosofis yang lebih mengejar kepentingan politik dan materi, hingga akhirnya pada periode Islam yang menjunjung tinggi nilai kemanusiaan dan keadilan menuju kesejahteraan keluarga di dunia dan akhirat. Ketiga, dimensi kejiwaan selalu tersentuh pada setiap elemen dari konsep keluarga Islam, bahkan pada ajaran Islam secara umum. Sebab, dimensi kejiwaan merupakan bagian yang tidak terpisahkan dari kehidupan manusia yang selalu dipelihara dan menjadi tujuan pensyariatan ajaran Islam. Keempat, psikologi keluarga Islam baru tampil sebagai sebuah kajian ilmiah secara khusus pada tahun 1980-an, setelah kajian psikologi keluarga terwacana di Barat sejak tahun 1960-an. Upaya konseptualisasi psikologi keluarga Islam ini tidak semata dimaksudkan untuk mengejar peradaban Barat, tetapi demi mengembalikan pemahaman umat kepada prinsip-prinsip dasar keislaman agar dapat membangun kesejahteraan keluarga yang hakiki. Kelima, konsep psikologi keluarga Islam berbeda dengan konsep psikologi keluarga dari produk Barat. Konsep psikologi keluarga produk Barat terlahir dari elaborasi multi disiplin ilmu (psikologi, sosiologi dan ekologi) dengan rasionalitas sebagai ciri khas pengamatannya. Sedangkan konsep psikologi keluarga Islam dilahirkan dari prinsip humanisme 
Islam, konsep keluarga dalam Al-Quran dan Sunnah, dan perangkat metodologi dalam psikologi Islam.

\section{Referensi:}

'Atiyyah, Jamal al-Din, Nahwa Taf'il Maqasid al-Shari'ah, Damaskus: al-Ma'had al'Alami li al-Fikr al-Islami, 2001

Ackerman, N.W., "A Dynamic Frame for the Clinical Approach to Family Conflict" dalam N.W.Ackerman, F.L.Beatman dan S.N.Sherman (Ees), Exploring the Base for Family Therapy, New York: Family Service Association of America, 1961.

Agus Miswanto, "Keluarga Sakinah dalam Perspektif Ulama Tafsir: Studi terhadap Rumah Tangga Nabi Adam", Cakrawala: Jurnal Studi Islam, Vol. 14 No. 2, Tahun 2019.

Al-'Aziz, Salih 'Abd, Al-Sihhah al-Nafsiyyah li al-Hayah al-Zawjiyyah, Kairo: al-Hay'ah al-Misriyyah al-'Ammah li al-Kitab, 1972.

al-Damashqi, Abu al-Fada' Isma'il ibn Kathir, al-Bidayah wa al-Nihayah, Ghizah Mesir: Dar Hajar, 1999.

Al-Kandari Ahmad Mubarak, 'Ilm al-Nafs al-Usri, Kuwait: Maktabah al-Fallah, 1992.

Al-Khuri, Tuma George, Sikulujiyyah al-Usrah, Beirut: Dar Al-Jayl, 1988.

Al-Rahman, Sa'ad 'Abd, Sikilulujiyyah al-Bi'ah al-Usriyyah wa al-Hayah, Kuwait: Maktabah al-Fallah, 2016.

al-Rahman, Su'ad 'Abd dkk, Sikulujiyyah al-Bi'ah al-Usriyyah wa al-Hayah, KuwaitEgypt: Maktabah al-Fallah, 2016.

Al-Rahman, Su'ad 'Abd dkk, Sikulujiyyah al-Bi'ah al-Usriyyah wa al-Hayah, KuwaitEgypt: Maktabah al-Fallah, 2016.

Al-Shati, 'Adnan 'Abd al-Karim, Mudhakarat fi Sikulujiyyah al-'Alaqat al-Usriyyah, Kuwait: Matabi' Kuwayt Taymuz, 1988.

Al-Zayn, Samih 'Atif, Ma'rifah al-Nafs al-Insaniyyah fi al-Kitab wa al-Sunnah, Beirut: Dar al-Kutub al-Lubnaniyyah, 1991.

Badri, Malik, The Dilemma of Muslim Psychologists, Terj. Muna Kantibay Abu Qarjah, Oman: Dar Dubaynu, 2010.

Barakat, Muhammad Khalifah, 'Ilm al-Nafs al-Tarbawi fi al-Usrah, Kuwait: Dar AlQalam, 1977.

Bray, James H dan Mark Stanton, 'Preface' The Wiley-Blackwell Handbook of Family Psychology, Blackwell Publishing Ltd, 2009.

Ema Yudiani, "Pengantar Psikologi Islam", dalam JIA, Vol.XIV, No.2, Desember 2013. Fa'iz, Ahmad, Dustur al-Usrah fi Zilal al-Qur'an, Beirut: Mu'assasah al-Risalah, 1992.

Howard A. Liddle, "Family Psychology: Editors Introductionl", Journal of Family Psichology: Department of Family and Community Medicine University of California, September 1987.

Iqbal Muhammad Bashir, Dinamikiyyah al-'Alaqat al-Usriyyah, (Iskandariyah: alMaktabah al-Jami'i al-Hadith, 1986), 122.

Kaslow, Florence W, "A Brief History of the Field of Family Psychology and Therapy" dalam Handbook of EMDR and Family Therapy Processes, New York: John Wiley \& Sons Inc, 2007. 
Lasiyo, "Sumbangan Filsafat Confucianisme dalam Menghadapi Abad XXI", Jurnal Filsafat Universitas Gajah Mada, (Yogyakarta: Desember 1994.

Mark Stanton, "The Systemic Epistemology of the Specialty of Family Psychology" dalam The Wiley-Blackwell Handbook of Family Psychology, Blackwell Publishing Ltd, 2009.

Mufidah Ch, Psikologi Keluarga Islam Berwawasan Gender, Malang: UIN Maliki Press, 2014.

Musa, Kamal Ibrahim dan Muhammad, 'Awdah: al-Sihhah al-Nafsiyyah fi Daw' 'Ilm alNafs wa al-Islam, Kuwait: Dar al-'Ulum, 1986.

Musa, Kamal Ibrahim, al-'Alaqah al-Zawjiyyah wa al-Sihhah al-Nafsiyyah: fi al-Islam wa 'Ilm al-Nafs, Kuwait: Dar Al-Qalam, 1995.

Nagy, Boszormenyi dan J.L.Framo, Intensive Family Therapy, New York: Brunner/Mazel, 1985.

Najati, Muhammad Uthmani, Al-Qur'an wa 'Ilm al-Nafs, Kairo: Dar al-Shuruq, 1985.

Raymond Dawson, Confucius, New York: Oxford University Press, 1981.

Saqar, 'Atiyyah, Mawsu'ah al-Usrah tahta Ri'ayah al-Islam, Kairo: Maktabah Wahbah, 2006.

Satir V, Conjoint Family Therapy, Palo Alto, CA: Science \& Behavior Books, 1967.

Therapy: Theory and Practice, New York: Gardner Press, 1976.

Whitaker, C.A, "The Hindrance of Theory in Clinical Work" dalam P.J.Guerin dkk, Family 